\title{
Editorial
}

\section{Intensive care medicine: a multidisciplinary approach!}

HUGO VAN AKEN, JANNICKE MELLIN-OLSEN AND PAOLO PELOSI

PUBLISHED WITH PERMISSION (EUROPEAN JOURNAL OF ANAESTHESIOLOGY 2011, 28:313-315)

\begin{abstract}
From the Department of Anaesthesiology and Intensive Care Medicine, University Hospital Munster, Munster, Germany (HVA), Multidisciplinary Joint Committee of Intensive Care Medicine of the UEMS, Brussels, Belgium (HVA), Department of Anaesthesiology and Intensive Care Medicine, Baerum Hospital, Oslo, Norway (JM-O), European Board of Anaesthesiology of the UEMS, Brussels, Belgium (JM-O), Dipartimento di Scienze Chirurgiche e Diagnostiche Integrate, University of Genoa, Genoa, Italy (PP) and European Society of Anaesthesiology, Brussels, Belgium (PP)
\end{abstract}

Correspondence to Hugo Van Aken, MD, PhD, FRCA, FANZCA, Department of Anaesthesiology and Intensive Care Medicine, University Hospital Munster, Albert-Schweitzer-Street 33, D-48149 Munster, Germany Tel: +49 251834 7251; fax: +49 251 88704; e-mail: hva@uni-muenster.de

Intensive care medicine (ICM) is unique in that it deals with the most severely ill patients in almost all fields of medicine. It is demanding in all aspects from a theoretical, practical, co-operational and personal perspective. It is also characterised by a rapid development in diagnostic and treatment options. Furthermore, the organisational and manpower characteristics of European healthcare have been changing over time. Hence, the official status of ICM warrants unbiased consideration.

One option to improve the visibility and attractiveness of ICM might be to aim to install a new primary speciality of ICM in Europe. Such a development may lead to more competent doctors in the ICUs and improve the status of ICM within the healthcare system.

Presently, the European Directive on recognition of professional qualifications (Directive 2005/36/EC of the European Parliament) does not identify ICM as a primary medical speciality. ${ }^{1}$ The European Union requires that, to become a primary speciality, it must be recognised in at least two fifths of the member states and, at the same time, by a particular majority (a weighted vote that is determined by the population of each country and other factors and giving what is called a 'qualified majority') in a committee on qualification of the European Commission (not only for medical professions but generally for all protected professions). In addition, to create a specialist section for ICM within the European Union of Medical Specialists (UEMS), ICM has to be recognised as an independent speciality by more than one third of the European Union member states and must be registered in the official journal of the European Commission (Medical Directives).

Currently, ICM is an independent speciality only in Spain (member of the European Union) and in Switzerland (member of the European economic area). In 10 countries of the European Union (Table 1), ICM can be practised as a 'particular qualification' with a common training programme for specialists with board certification in a variety of base disciplines (anaesthesiology, cardiac surgery, cardiology, internal medicine, neurology, neurosurgery, paediatrics, respiratory medicine and surgery). A 'particular qualification' is an area of expertise in addition to a primary speciality qualification in which extra expertise outside the domain of the primary speciality is required to provide high-quality patient care.

In the remaining 17 countries of the European Union and the remaining two countries of the economic area, ICM is part of the training programme of anaesthesiology (among others) with different lengths of training varying from 6 to 24 months. However, the training programme for anaesthesiology also ranges from 36 to 72 months in these countries.

As the requirements for a primary speciality are not fulfilled for ICM, this would be a cumbersome way, but worth the effort if it is considered beneficial to acquire this status. A better way forward is to incorporate ICM as a 'particular qualification' in the revision of the European Directive 2005/36/EC in the year 2012.

In a meeting of the Multidisciplinary Joint Committee of Intensive Care Medicine of the UEMS (MJCICM) in April 2008, the nine medical disciplines involved in ICM voted against the idea that ICM should become an independent primary speciality. On 19 April 2008, this proposal was supported by an overwhelming majority of the members of the Council of the UEMS.

The reasons are rational and obvious. Most importantly, ICM is considered to be too complex to be covered by one medical speciality alone. Rather, the close co-operation of physicians treating the underlying disease and of physicians treating accompanying organ dysfunction and failure, and - if required - of specialists for extraordinary clinical problems, is necessary. A separation of ICM would tend to impede this mutual communication and collaboration among different professionals with specific knowledge, expertise and skills, rather than foster it.

Thus, a multidisciplinary approach is necessary to facilitate the required high-level quality ICM for the critically ill patient. However, ICUs also need a clearly defined ICU leader to ensure a sound structure and delivery of a high level of care. The basic primary medical speciality of ICU leaders may differ. ${ }^{2}$ Another important aspect with respect to the organisational structure of ICUs is the question of whether outcomes of patients treated on specialised units 
Table 1 Countries where intensive care medicine can be practised

\begin{tabular}{|c|c|c|c|}
\hline Country & Intensive care medicine (title) & $\begin{array}{l}\text { Period of training } \\
\text { (months) }\end{array}$ & Additional comments \\
\hline Austria & $\begin{array}{l}\text { Facharzt für Anästhesie und Intensivmedizin } \\
\text { (Additivfach: for other specialties) }\end{array}$ & 18 & $\begin{array}{l}\text { Intensive care medicine is part of the training programme of anaesthesia ( } 72 \\
\text { months) }\end{array}$ \\
\hline Belgium ${ }^{a}$ & $\begin{array}{l}\text { Bijzondere beroepstitel in de intensieve zorg - Titre } \\
\text { professionel particulier de compétence en soins intensifs }\end{array}$ & 24 & Up to 12 of these 24 months may be integrated in the basic speciality \\
\hline Bulgaria & $\begin{array}{l}\text { Specialist in Anaesthesiology and Intensive Care } \\
\text { Medicine }\end{array}$ & 18 & $\begin{array}{l}\text { Intensive care medicine is part of the training programme of anaesthesia (60 } \\
\text { months) }\end{array}$ \\
\hline Cyprusa & Entaticologia & 24 & $\begin{array}{l}24 \text { months in addition to basic speciality training (anaesthesiology, cardiology, } \\
\text { internal medicine, surgery and paediatrics) }\end{array}$ \\
\hline Czech Republic & Nástavbová specializace & 24 & $\begin{array}{l}12 \text { months of general intensive care along with } 12 \text { months of modified profile } \\
\text { (paediatric, surgical and non-surgical) }\end{array}$ \\
\hline Denmark & Fagomrade & 24 & $\begin{array}{l}\text { Total } 84 \text { months: } 12 \text { months of basic anaesthesiology introduction }+48 \\
\text { months of general anaesthesiology followed by } 24 \text { months }\end{array}$ \\
\hline Estonia & Anestesioloog ja intensiivravi arst & 20 & $\begin{array}{l}\text { Intensive care medicine is part of the speciality called anaesthesia and inten- } \\
\text { sive care and is included in the anaesthesiology training (total } 48 \text { months) }\end{array}$ \\
\hline Finland & $\begin{array}{l}\text { Tehohoitolääketiede (specialist in } \\
\text { Anaesthesiology and Intensive Care Medicine) }\end{array}$ & NA & $\begin{array}{l}\text { Intensive care medicine is part of the training programme of anaesthesia ( } 72 \\
\text { months) }\end{array}$ \\
\hline France & Réanimation Médicale & 24 & $\begin{array}{l}\text { Integrated in part in the anaesthesia and intensive care medicine programme } \\
\text { (in total } 60 \text { months) }\end{array}$ \\
\hline Germanya & Zusatzweiterbildung Intensivmedizin & 24 & $\begin{array}{l}\text { Up to } 12 \text { of these } 24 \text { months may be integrated in the training programme } \\
\text { anaesthesiology. Up to } 6 \text { of these } 24 \text { months may be integrated in the training } \\
\text { programme for basic specialities - surgery, internal medicine, neurology, neurosur- } \\
\text { gery or paediatrics }\end{array}$ \\
\hline Greece $^{a}$ & Entatikh latrikh & 24 & $\begin{array}{l}24 \text { months in addition to basic speciality training(anaesthesiology, cardiol- } \\
\text { ogy, internal medicine, surgery and paediatrics) }\end{array}$ \\
\hline Hungary & Ráépített Intenzív Terapia & 24 & $\begin{array}{l}6 \text { months of anaesthesiology, } 12 \text { months of general intensive care, } 6 \text { months } \\
\text { of special intensive care (total } 60 \text { months) }\end{array}$ \\
\hline Irelanda & $\begin{array}{l}\text { Diploma of the Irish Board of Intensive } \\
\text { Care Medicine (DIBICM) }\end{array}$ & $12+24$ & $\begin{array}{l}\text { After } 36 \text { months Fellow of the Joint Faculty of Intensive Care Medicine of } \\
\text { Ireland (FJFICMI) }\end{array}$ \\
\hline Italy & $\begin{array}{l}\text { Societa' Italiana Anestesia, Analgesia, } \\
\text { Rianimazione e Terapia Intensiva (SIAARTI) }\end{array}$ & 24 & 60 months for the whole course \\
\hline Latvia & $\begin{array}{l}\text { Anaesthesia and Reanimatology } \\
\text { (Intensive Care) }\end{array}$ & 12 & $\begin{array}{l}60 \text { months in total ( } 5 \text { years training in anaesthesia and } \\
\text { intensive care) }\end{array}$ \\
\hline Lithuania & Anesteziologas reanimatologas & $14+25$ & Total training duration is 48 months \\
\hline Luxembourg & NA & NA & NA \\
\hline Malta & $\begin{array}{l}\text { Anaesthesia and Intensive Care } \\
\text { Medicine }\end{array}$ & 12 & Intensive care is part of the training programme of anaesthesia (60 months) \\
\hline $\begin{array}{l}\text { The } \\
\text { Netherlands }\end{array}$ & $\begin{array}{l}\text { Anaesthesiologist-intensivist, Internistintensivist, } \\
\text { Surgeon-intensivist, Neurologist-intensivist, etc. }\end{array}$ & 24 & 12 months included in the basic speciality (total 72 months) \\
\hline Poland & Specijalista anestezjolog & 24 & Included in the 72 months training of anaesthesiology \\
\hline Portugala & Medicina Intensiva & 24 & $\begin{array}{l}2 \text { years of training after the completion of a primary speciality(e.g. anaesthe- } \\
\text { sia, internal medicine and surgery), in an ICU classified by the National Medical } \\
\text { Board as level C, with a final theoretical and clinical exam; regulations, require- } \\
\text { ments and final exam independent from the primary speciality }\end{array}$ \\
\hline Romania & Anaesthesia and Intensive Care Medicine & 24 & Total duration 60 months \\
\hline Slovakia & Anaesthesia and Intensive Care Medicine & 18 & Total duration 60 months \\
\hline Slovenia ${ }^{a}$ & $\begin{array}{l}\text { Multidisciplinary specialisation of intensive care } \\
\text { medicine }\end{array}$ & 24 & $\begin{array}{l}\text { Basic speciality in anaesthesiology, reanimation, perioperative intensive medi- } \\
\text { cine (total } 60 \text { months) (additional specialisation } 24 \text { months) }\end{array}$ \\
\hline Spain $^{\mathrm{a}}$ & Anestesiología y Reanimación & $6+12$ & Included in the 48 months training of anaesthesiology \\
\hline Spain $^{\mathrm{b}}$ & Especialistas en medicina intensiva & 32 & Primary speciality 56 months in total \\
\hline Sweden & $\begin{array}{l}\text { Anaesthesia and Intensive Care } \\
\text { Medicine }\end{array}$ & 12 & $\begin{array}{l}\text { Additional } 12 \text { months in intensive care voluntary on top of the total } \\
\text { programme (60 months) }\end{array}$ \\
\hline UKa & Specialist Register' for Intensive Care Medicine & $12+24$ & $\begin{array}{l}\text { Doctors wishing to undertake training in the speciality of intensive care medi- } \\
\text { cine must presently acquire it jointly with one of the specialities of primary } \\
\text { appointment of anaesthesia, emergency medicine, internal medicine or surgery }\end{array}$ \\
\hline $\mathrm{UK}^{\mathrm{b}}$ & CCT 'Intensive Care Medicine’ & 84 & New in 2011: Intensive care medicine as a primary speciality \\
\hline \multicolumn{4}{|c|}{ European Economic Area } \\
\hline Iceland & & 6 & $\begin{array}{l}\text { No particular medical qualification in anaesthesiology, } 6 \text { months of intensive } \\
\text { care medicine training is required }\end{array}$ \\
\hline Norway & No official title & $6+24$ & $\begin{array}{l}\text { Only anaesthesiologists do minimum } 6 \text { months of intensive care medicine } \\
\text { training as part of their postgraduate education. In addition, anaesthesiolo- } \\
\text { gists can do an additional master class through the Scandinavian Society and } \\
\text { receive a diploma ( } 24 \text { months with courses in all Scandinavian countries along } \\
\text { with passed ESICM Diploma examination) }\end{array}$ \\
\hline Switzerland ${ }^{b}$ & Facharzt für Intensivmedizin & 72 & Total 72: up to 30 months in base speciality are accepted \\
\hline
\end{tabular}

NA, not applicable. ${ }^{a}$ Countries that have a particular competence in intensive care medicine on top of a primary speciality. ${ }^{\mathrm{b}}$ Countries where intensive care medicine is a primary speciality. 
are better than those of patients on general ICUs. It has often been suggested that ICUs with greater diagnostic diversity are associated with worse outcome. However, the opposite is true, as demonstrated recently in two larger studies. ${ }^{3,4}$

Current evidence indicates that patient outcomes are better when patients are cared for by trained intensivists. ${ }^{5}$ In Europe, this can be achieved by facilitating the acquisition of agreed common competencies in ICM by trainees from the various primary speciality training programmes involved in ICM.

Furthermore, as ICM is extremely demanding physically and mentally, one would expect that severe problems will occur with physicians who will have to leave ICM after some years due to 'burnout'. ${ }^{6}$ Creating ICM as a primary speciality would disqualify them from working in another specialism, whereas the 'particular qualification' concept allows them to return to their 'mother disciplines' or to rotate back there for some time.

ICM was the first discipline in Europe to develop a multidisciplinary training programme based on the acquisition of competencies: clearly defined sets of knowledge, skills, attitudes and behaviours which together define the basic abilities of an 'intensivist'. The CompetencyBased Training in Intensive Care in Europe (CoBaTrICE) project and training programme (www.cobatrice.org), supported by a grant from the European Community's Leonardo Programme, undertook an international survey of training in adult ICM ${ }^{7}$ and, using consensus techniques, defined the core (minimum) competencies required of a specialist. $^{8}$ In the survey of ICM training programmes in European Union Member States, the median duration of training is 24 months. The 102 competencies defined by the CoBaTrICE programme provide a sound basis for identifying ICM within the directive as a 'particular qualification'.

The European Society of Anaesthesiology (ESA), the European Board of Anaesthesiology of the UEMS (EBA) and the Multidisciplinary Joint Committee of Intensive Care Medicine (UEMS MJCIM) do not support the proposal that ICM should become a primary specialty, as suggested in a recent article in The Lancet. ${ }^{9}$ Building new fences between areas of medicine is counterproductive with regard to the challenges of modern medicine. The aim should rather be that doctors with various relevant backgrounds and common formalised additional training work together to the benefit of each individual patient and the improvement of quality of ICM.

This article was checked and accepted by the Editors, but was not sent for external peer-review.

\section{References}

1 The European Parliament and the Council of the European Union. Directive 2005/36/EC of the European Parliament and of the Council of 7 September 2005 on the recognition of professional qualifications. http:// eur-lex.europa. eu/LexUriServ/LexUriServ.do?uri=0J:L:2005:255:0022 : 0142:en:PDF [Access 3 August 2011].

2 Brilli RJ, Spevetz A, Branson RD, et al. Critical care delivery in the intensive care unit: defining clinical roles and the best practice model. Crit Care Med 2001; 29:2007-2019.

3 Volkert T, Hinder F, Ellger B, Van Aken H. Changing from a specialized surgical observation unit to an interdisciplinary surgical intensive care unit can reduce costs and increase the quality of treatment. Eur $J$ Anaesthesiol 2008; 25:382-387.

4 Lott JP, Iwashyna TJ, Christie JD, et al. Critical illness outcomes in specialty versus general intensive care units. Am J Respir Crit Care Med 2009; 179:676-683.

5 Pronovost PJ, Angus DC, Dorman T, et al. Physician staffing patterns and clinical outcomes in critically ill patients: a systematic review. JAMA 2002; 288:2151-2162.

6 Raggio B, Malacarne P. Burnout in intensive care unit. Minerva Anestesiol 2007; 73:195-200.

7 Barrett $\mathrm{H}$, Bion JF. An international survey of training in adult intensive care medicine. Intensive Care Med 2005; 31:553-561.

8 The CoBaTrICE Collaboration. Development of core competencies for an international training programme in intensive care medicine. Intensive Care Med 2006; 32:1371-1383.

9 Moreno RP, Rhodes A. Intensive care medicine: a specialty coming to LIFE. Lancet 2010; 376:1275-1276. 